\title{
SLC5A5 wt Allele
}

National Cancer Institute

\section{Source}

National Cancer Institute. SLC5A5 wt Allele. NCI Thesaurus. Code C52303.

Human SLC5A5 wild-type allele is located within 19p13.2-p12 and is approximately $22 \mathrm{~kb}$ in length. This allele, which encodes sodium/iodide cotransporter protein, plays a role in the mediation of iodide transport into the thyroid. Mutations in the gene are linked to hypothyroidism due to an iodide transport defect. 